\title{
Gillian Sands Memorial Issue
}

This issue of LIM is dedicated to the life and work of Gillian Sands, our much loved colleague who sadly died on the $31^{\text {st }}$ January this year, leaving the profession and her colleagues much too soon and denying us the pleasure, both personal and professional, of seeing such a wonderfully promising life and career blossom and flower. The Editorial is devoted to personal reminiscences by Gillian's friends and colleagues. The issue itself has an international theme as reflecting Gillian's interests, but it also includes articles which illustrate different phases of Gillian's all too brief life. To everyone who has written for us, the Editorial Board is most grateful and we hope that Gillian's family will receive some comfort from seeing in just what high esteem Gillian was held in the legal information profession.

\section{David Gee}

Gillian Sands was appointed to the Academic Services department of IALS Library in December 2000 and, as Academic Services Manager, I was lucky enough to become her line manager until she left the Institute for the Bodleian Law Library in December 2004. Gillian sat at the desk next to me throughout these four years and I got to know her well as a delightful and bubbly person who genuinely cared about the well being of the library readers and her library colleagues.

Gillian was a key member of my Academic Services team and contributed a great deal to the improvement of our library services and library collections throughout her time at IALS. Her main role was to deliver proactive library support services for the University of London intercollegiate LLM programme. This programme is the largest in Europe with a total of nearly I,500 registered students who each choose four LLM courses from a possible 140 different options to complete in one year. As LLM Services Librarian, Gillian used to request reading lists from lecturers and then check them for new material, spend allocated budgets on purchasing these books and serials, and develop the library's electronic and web resources for the LLM students. She also successfully organised the library's contribution to the annual Induction Day for new LLM students and spoke at many of the University of London college library induction days. Throughout her time here, Gillian undertook these duties with professionalism, much hard work and flair.

Gillian was also an excellent team player and all the Academic Services team (myself, Paul Norman, Gerry Power and Katherine Read) enjoyed working closely with her on improving the range of library services. In particular, between us we spent much time developing the library's public training programme and improving the value-added services on the library website. Gillian, for instance, impressively revised the Belgium, Luxembourg and Italy country research guides.

Gillian also helped and supported me in developing many new projects and services. For example she assisted me with the important project to completely update the library signage. Together, over several months, we met a number of signage contractors whose wares ranged from the downright indifferent to the exciting, and learnt much more than we really needed to know about what makes for effective signage! The successful and professional results of the project can be seen on the walls and pillars all around the library.

Finally Gillian had important responsibilities managing the Enquiry Desk staff, two junior Academic Services staff and the casual shelving staff. These duties meant that she often helped to recruit, train and supervise staff, many of which are still working here today. Gillian was very much a nurturing manager, combining strength of purpose and practical ideas with an encouraging and caring nature.

Gillian was a very thoughtful and kind person who instinctively thought the best of people. In public she was always calm and wholly professional. However, in private, like many of us, she was sometimes understandably nervous and under-confident and appreciated encouragement and reassurance before taking issues forward. She was very good at thinking about the other person's point of view and would always sensibly try to take into account all voices when coming to a final decision. Above all, though, Gillian was continually sensitive to the needs 
of the readers and concerned for the well being of her colleagues. This made her a wonderful person to work with each day and an impressive role model to remember with much affection and appreciation.

\section{Alison Cowen \& Emily Allbon}

Alison Cowen: I was lucky enough to know Gill both professionally and socially for around six years. I first met Gill in 1998 when we were studying for our MSc in Information Science at City University. I remember being struck by how bright Gill was and her real enthusiasm for the course. Fortunately for me, a group project early on in the year meant that I had the pleasure of working closely with her and our friendship developed from there. Life would have been much tougher without Gill to call or meet up with during the long months of dissertation writing.

Emily Allbon: I met Gill the year after this when she began work at the IALS as I had retained some hours there whilst doing my MSc at City. We soon became friends and the prospect of a year-long course stretching ahead seemed far less daunting when she talked about it so passionately. Unlike many, she saw the course as far more than a means to an end, and throughout the year she was the one person who could be relied upon to spur me on through the vagaries of information retrieval. The fact that I invited her to my wedding after only knowing her for a few months showed the impact she had on me I imagined she would be a lifelong friend.

Gill's passion for law librarianship has been such a huge source of motivation for others over the years. It was difficult not to smile when she described how excited she was about the training she was giving or the work she was doing with the LLM students and teachers. She even managed to have positive things to say about the annual stock take!

Gill really loved working closely with the readers and welcomed any feedback, good or bad. She enjoyed giving group tours and being able to adapt every one to suit the particular interests of the party. Her motto on the enquiries desk was always to give a bit more than was being asked of her wherever possible. In fact this was something that Gill did in every aspect of her life. It is worth noting that even people who hadn't even met her in person had her down as a "lovely person, always willing to help" (as said by a City University LLM administrator who had only communicated with Gill through email).

Gill put a great deal of energy and effort into attaining chartership status. It was a credit to her that she managed to start her chartership programme only months after completing her MSc. She was proactive in arranging visits to law libraries for herself and others, and signing up for tours organised by the Government Libraries Group and the City Legal Information Group.
Years after she chartered she continued to visit other libraries. A trip to the Women's Library in 2003 appealed to Gill because of an exhibition about Votes for Women and it gave her the chance to explore a part of London that she was not so familiar with.

The BIALL Law for Law Librarians course and the BIALL conferences Gill attended gave her the opportunity she relished to mix with other law librarians. Typical of Gill was when she travelled up on the train to the BIALL conference in 2004 with a visiting Law Librarian from Cape Town and how much she enjoyed talking to her. Her absence from the conference this year was keenly felt; it was strange to look round and not see her there chatting to one of the many BIALL members she knew.

Outside law librarianship Gill had a large number of interests. She enjoyed almost everything to do with the arts. The number of theatre productions, exhibitions and concerts she attended would be impossible to count. Travel was another huge part of Gill's life. She went to America and Canada with friends and regularly went down to Dorset. She loved being close to nature and spent much happy time wandering along the beach and coastal paths or the woodlands. Many of her friends have lovely memories of going to Abbotsbury Swannery with Gill, or having a picnic or cream tea on a sunny afternoon.

London was another of Gill's loves. She would try as much as possible to walk from the mainline station to work when she was based at the Institute of Advanced Legal Studies and in her spare time she would roam around the city visiting galleries, museums and parks. She made every effort to take advantage of Open House London or events like ice skating at Somerset House. She was a wonderful guide to others when it came to places to visit or restaurants to go to. Every year for her birthday she would find a new bar or restaurant and never be afraid to go somewhere different.

Her character was always surprising; on one hand she came across as quiet and reserved but people meeting her for the first time would feel immediately

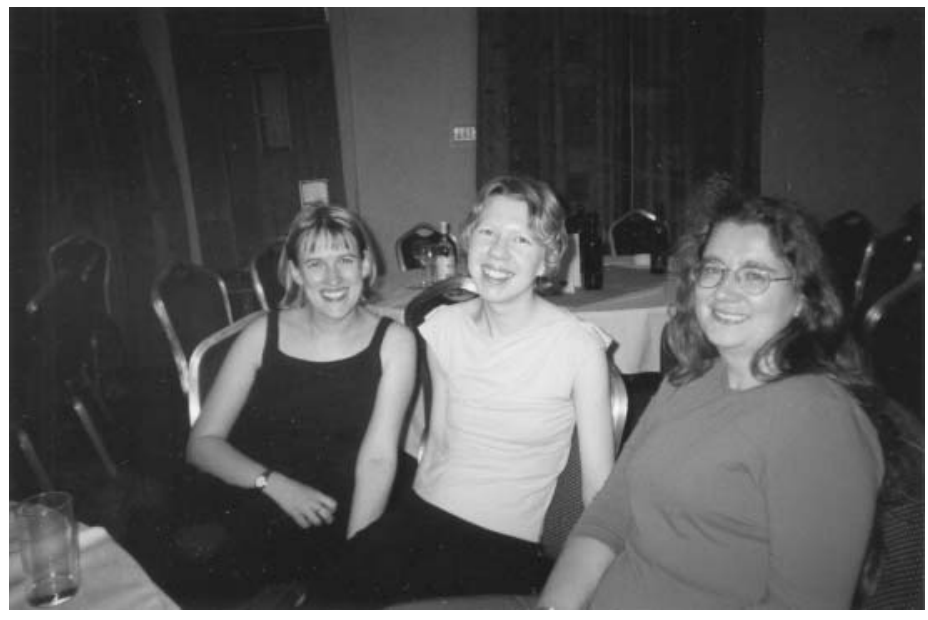

Wendy Lynwood (Birkbeck College), Gillian \& Lindsey Caffin (IALS) at BIALL Conference, Liverpool 2002. 
at their ease as her demeanour showed she was so interested in them and what they had to say. She fiercely stuck to what she believed in; a slight flouting of copyright law I once jokingly suggested (EA) was adamantly refused even though she was my friend. Her holiday to the States was a huge adventure with Gill doing much of the driving through busy US cities and across interstates - something neither of us would contemplate without a shudder!

Gill was a very caring and kind friend, who had a real sense of empathy. One year for my birthday (AC) she took the whole day off work to get ready and arrived miles earlier than anyone else because she knew how hard it was to be the hostess of a party. She would often buy friends clothes for their birthday and given how hard it can be to buy clothes for yourself, she was always spot on and delighted when she saw your face. I think this shows just how much attention she paid to her friends. Last July she ran the "Race for Life" for Cancer Research UK in St Albans. She was so pleased that she managed to run over half the course and that she had done a little something to help conquer cancer.

She received a "first class Librarian" mug from a colleague on her $30^{\text {th }}$ birthday and it really speaks volumes about her. Gill was a first class Librarian but also a first class friend. We will remember her as many of you who knew her will - laughing happily, head thrown back in hilarity.

\section{Martin Reid}

Gillian started her career as a librarian at University College London where she was a Student Assistant, sometimes known as a graduate trainee, from 19971998. During that time she worked in a number of different departments and locations where she layed the foundations and gained a lot of the necessary experience for her subsequent career in academic libraries. Most of

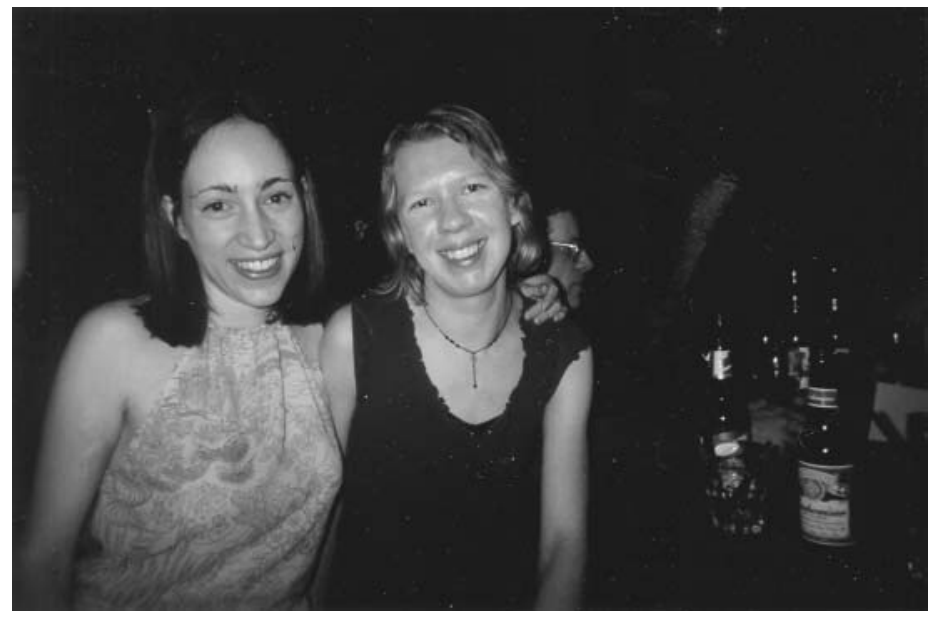

Nicola Cowen and Gillian taken at Nicola and Alison Cowen's Birthday Party, April 2003. her time was divided between Periodicals and the issue desk in the Main Library where she encountered sometimes demanding law students for the first time. She also worked in the Boldero Library in the Middlesex Hospital and the Science Library where she assisted subject librarians covering Maths \& Physical Sciences. Wherever she worked, however, she always impressed everyone with her hard work and commitment. Reports from her supervisors were always excellent and her colleagues recall how even at this early stage just what a total professional she was. Fellow trainees always knew she would do well and could easily see her as librarian of a major institution one day. However, what comes across most strongly from the many colleagues here who worked with her then and recall her with great affection, is that as well as being diligent and enthusiastic, she was a lovely person with a great sense of humour, who they all liked and valued very much, and who did a great deal to make the Library an enjoyable place to work. She took these qualities with her to the Institute of Advanced Legal Studies and it was a great pleasure for me to work with her again from time to time when she took over responsibility for supporting the LLM programme there and began to liaise with the law librarians at the various University of London law schools. She was a marvellous colleague and friend and will be missed very much by all knew her here at UCL.

Dr Paul Ayris, Director of Library Services at UCL, writes in addition: "I first met Gillian Sands in 1997, as she and I were appointed to the staff of the Library in University College London, as it was then called, at around the same time. She was bright, enthusiastic and eager to become a librarian in an academic library. UCL has a remarkable record in employing young library assistants who later go on to achieve some prominence in the profession. I remember wondering at the time whether Gillian would add to the number. She left UCL in August 1998 and the news of her untimely death is a great shock to those who worked with her. We will remember her openness and cheerfulness, and the contribution she made to us whilst she was here."

\section{Peter Clinch}

The death of a respected colleague is a severe loss. The death of a young, respected colleague whose career potential had yet to be fully realised and who was also a sincere and caring person, is an inestimable loss to our profession and the world in general.

I had come to know Gillian while I spent nearly three years working on the FLAG Project, based in the IALS. She always showed a professional and lively interest in the work undertaken by others and, more than that, a concern for each as a person. Her nature was sensitive, warm and outgoing. She fitted so well into the close-knit, friendly 
team at the IALS. I remember particularly her ready smile and joyful sense of humour.

She was conscientious in all she attempted - perhaps she was not fully aware of the stress-inducing danger this personal trait can create.

When she had obtained the foreign and international law specialist post at the Bodleian, she wrote to me of her excitement and the opportunity it held out to widen her experience. The post, she said, would offer an attractive mix of responsibilities. I warmly congratulated her for I could think of no one in the young generation of law librarians either so well experienced in the subject area or better suited to work in one of the leading academic law libraries in the UK. All the knowledge and experience she had gained at the IALS could now be applied and further enhanced at the Bodleian, for the benefit of its discerning users. Unfortunately, the promise was not to be.

Thank you, Gillian, for your life and example - you have left fond and lasting memories with all those who knew you.

\section{Endnotes}

\section{Don Raistrick}

We regret that in the Summer issue, Don's award was misstated - he did in fact get an OBE not an MBE.

\section{Christine Miskin}

\title{
A Career in Law Librarianship: In Memory of Gillian Sands
}

\author{
Jules Winterton, Librarian and Deputy Director - Institute of Advanced Legal \\ Studies.
}

At the time of her tragic death, Gillian Sands had already established a successful career in law librarianship. She had trained at City University School of Information Science and worked in professional posts at two of the most prestigious legal research libraries in the UK. Gillian had also made friends at each stage of her career across all sectors of law librarianship and was highly valued by those with whom she had worked. She had played an important role in the social life of her workplace as well as being valued for her dedication, conscientiousness and initiative. As a tribute to Gillian, this article traces her career in law librarianship and her various achievements. I record my thanks to her friends and colleagues Alison, Caroline, Christine, Emily, Wendy, and others who wrote to me in February this year.

Gillian attended the University of Southampton between 1994 and 1997 reading for a BA in history. She won prizes for her performance in both her second and her final year history courses and was awarded a first class degree with honours.

Gillian had worked at Westminster Abbey bookshop during her gap year in 1993 and, during the vacations while studying for her degree, she worked as a steward at St Pauls Cathedral dealing with visitor enquiries, selling tickets and stewarding at services and on galleries. In retrospect one vacation period in the summer of 1996 stands out in terms of Gillian's choice of career - a period of six weeks voluntary work in the business library at the University of Westminster. Her responsibilities included journals management, inter-site reservations and helping with record enquiries and stock check. Clearly Gillian had identified librarianship as a possible career choice.

On completion of her degree in the following year Gillian obtained a one-year training post as Student Assistant in the library services of the University College London from August 1997. She had the opportunity to work in the Middlesex Hospital library and the History of Science/Mathematics library as well as in the periodicals department and at the main library issue desk. Gillian proved herself to be a thorough, painstaking and hardworking Student Assistant who related well to other colleagues. "She is a modest person who made considerable achievements in her own quiet way." Gillian also impressed by her performance in directly assisting 